Jurnal Agro 8(1), 2021

\title{
KERAGAMAN GENETIK DAN HERITABILITAS 12 GENOTIPE BAWANG MERAH (Allium cepa L. var Aggregatum) DI DATARAN TINGGI
}

\section{GENETIC VARIABILITY AND HERITABILITY OF 12 SHALLOT GENOTYPES (Alllium cepa L. var Aggregatum) IN HIGHLAND}

\author{
Nurmalita Waluyo ${ }^{1,2^{*}}$, Noladhi Wicaksana ${ }^{1}$, Anas ${ }^{1}$, Iteu M. Hidayat ${ }^{2}$ \\ ${ }^{1}$ Departemen Budidaya Pertanian, Fakultas Pertanian, Universitas Padjadjaran JI. Raya \\ Bandung-Sumedang KM-21, Jatinangor 45363 \\ ${ }^{2}$ Balai Penelitian Tanaman Sayuran JI. Tangkuban Perahu No. 517, Lembang, Bandung Barat \\ 40391 \\ *korespondensi: nurmalitawaluyo@gmail.com
}

Diterima : 11 September 2020 / Disetujui : 27 Januari 2021

\begin{abstract}
ABSTRAK
Bawang merah (Allium cepa L. var aggregatum) salah satu komoditas hortikultura banyak di konsumsi. Peningkatan permintaan dalam kuantitas dan kualitas untuk komoditas ini meningkatkan ketersediaan varietas unggul. Penelitian dilakukan untuk menduga keragaman genotipe dan fenotipe serta nilai heritabilitas karakter pertumbuhan, komponen hasil dan hasil bawang merah di tiga lokasi dataran tinggi (Lembang 1.250 m dpl, Kab. Bandung Barat; Pacet 971 m dpl, Kab. Bandung; dan Samarang, 970 m dpl, Kab. Garut). Penelitian dilaksanakan dari September sampai Nopember 2019. Materi genetik yaitu 12 genotipe bawang merah terdiri dari 7 klon: B1, B19, B63, B72, B77, B102, dan B222, serta 5 varietas: Trisula, Bali Karet, Maja Cipanas, Bima Brebes dan Sumenep. Rancangan percobaan menggunakan Rancangan Acak Kelompok (RAK) dengan 3 ulangan. Hasil analisis ragam menunjukan genotipe berpengaruh sangat nyata terhadap seluruh karakter pertumbuhan, komponen hasil, dan hasil. Nilai koefisisen keragaman genotipe dan fenotipe yang tinggi diperlihatkan oleh karakter persentase tanaman berbunga (48,10 \% dan 49,01\%), berat basah per umbi (29,71\% dan 30,87 \%), dan berat kering per umbi $(33,17 \%$ dan $34,29 \%)$. Nilai duga heritabilitas arti luas $\left(\mathrm{H}_{\mathrm{bs}}\right)$ karakter pada 12 genotipe bawang merah berkisar antara 45,08-96,30\%. Semua karakter yang diuji memiliki nilai heritabilitas tinggi kecuali untuk karakter jumlah daun per rumpun nilai heritabilitasnya sedang. Seleksi bawang merah di dataran tinggi dapat dilakukan pada generasi awal.
\end{abstract}

Kata kunci: keragaman genetik, keragaman fenotip, heritabilitas, bawang merah

\section{ABSTRACT}

Shallots (Allium cepa L. var aggregatum) are one of the most widely consumed horticultural commodities in Indonesia. Increased demand in quantity and quality for this commodity improved availability varieties. A study was conducted to estimate variability of genotypes and phenotypes as well as the heritability value of growth characters, yield components, and yields heritabilitas 12 genotipe bawang merah (Alllium cepa L. var Aggregatum) di dataran tinggi. Jurnal Agro, 8(1), 1-13. https://doi.org/10.15575/9518 
of shallot at three highland locations (Lembang 1.250 m asl, West Bandung District; Pacet 971 m asl, Bandung District; and Samarang 970 m asl, Garut District). The research was conducted from September to November 2019. The genetic material studied was 12 genotypes of shallots consisting of 7 clones: B1, B19, B63, B72, B77, B102, and B222, and 5 varieties: Trisula, Bali Karet, Maja Cipanas, Bima Brebes, and Sumenep. Every experiments in all locations was arranged in Randomized Block Design (RBD) with 3 replications. The analysis of variance results showed that the genotype had a very significant effect on all growth characters, yield components, and yields. High variation coefficient values of genotype and phenotype was found in the character of percentage of flowering plants ( $48.10 \%$ and $49.01 \%)$, freshweight per bulb (29.71\% and $30.87 \%)$, and dry weight per bulb (33.17\% and $34.29 \%)$. All characters tested had a wide phenotific variability. The estimated value of heritability (broad meaning) of the characters in 12 shallot genotypes ranged from 45.08 to $96.30 \%$. All characters tested has high heritability except for the number of leaves per clump the heritability was moderate. The study is the shallot selection in the highlands can be carried out in the early generations.

Keywords: genetic variability, phenotype variability, heritability, shallot

\section{PENDAHULUAN}

Bawang merah (Allium cepa L. var aggregatum) merupakan salah satu komoditas hortikultura di Indonesia yang banyak di konsumsi. Produktifitas bawang merah dipengaruhi oleh musim. Khususnya di daerah Brebes yang merupakan sentra bawang merah di Indonesia, musim tanam atau "on season" dilakukan pada bulan April, Juli, dan Oktober sedangkan "off season" atau musim luar tanam pada bulan Januari - Maret. Pada saat musim panen maka bawang merah akan tersedia dalam jumlah yang banyak namun apabila sudah melewati musim tanam maka persediaan bawang merah nasional menjadi menurun drastis dengan harga yang tinggi.

Akibat kendala tersebut, maka
penanaman bawang merah dapat
diarahkan ke dataran tinggi. Menurut
Kementrian Pertanian (2020) potensi
ketersediaan sumber daya lahan untuk
pengembangan tanaman cabai dan bawang
merah di dataran tinggi mencapai 154,1
ribu hektar. Bawang merah dapat tumbuh
baik dari dataran rendah sampai dataran
tinggi dan penanaman dapat dilakukan

sepanjang tahun, asalkan kebutuhan air tercukupi. Karakter bawang merah yang penting yaitu warna umbi, ukuran umbi dan bentuk umbi sesuai dengan preferensi konsumen bawang merah, yaitu berwarna merah tua, berukuran 2,5-3 cm, bentuk umbi bulat atau agak bulat (Basuki, 2009), sedangkan bawang merah yang banyak ditanam di dataran tinggi umumnya berbentuk pipih agak bulat. Oleh karena itu, penyediaan varietas unggul untuk dataran tinggi perlu dilakukan.

Perakitan varietas unggul bawang merah ditujukan untuk memperbaiki varietas dalam upaya peningkatan daya hasil, perbaikan kualitas umbi, peningkatan ketahanan/toleransi tanaman terhadap cekaman biotis dan abiotis. Salah satu tahap dalam perakitan varietas bawang merah yaitu seleksi. Faktor yang menjadi kunci keberhasilan seleksi antara lain adalah tersedianya informasi keragaman genetik dan heritabilitas karakter-karakter yang menjadi target program seleksi. Analisis keragaman genetik dari setiap sumber daya genetik yang tersedia perlu dilakukan untuk mendapatkan data deskripsi atau karakter spesifik dari masing-masing genotipe baik 
secara morfologi maupun molekuler (Sari et al., 2017).

Uji multilokasi juga dapat menduga ragam genetik lebih baik dibandingkandengan ragam genetik yang diduga hanya dari satu lingkungan, karena dengan uji mul-tilokasi dapat menduga ragam interaksi genetik dengan lingkungan. Suatu karakter banyak dipengaruhi oleh faktor genetik atau lingkungan dapat diketahui dengan menghitung nilai duga heritabilitas arti luas. Nilai heritabilitas yang tinggi untuk suatu karakter menunjukkan pengaruh faktor genetik lebih besar dibandingkan faktor lingkungan dan memiliki peluang yang besar untuk diwariskan pada turunnanya (Hermanto et al., 2017). Menurut Nasution (2010) karakter hasil merupakan karakter kompleks yang sangat dipengaruhi oleh karakter pertumbuhan dan komponen hasil. Penampilan tanaman berbeda pada kondisi iklim yang bervariasi dan varietas dari spesies yang sama yang dibudidayakan di lingkungan yang sama memberikan hasil yang berbeda karena potensi tanaman tergantung pada interaksi genetik dan lingkungan (Visalakshi et al., 2018)

Informasi mengenai keragaman genetik dan heritabilitas bawang merah di Indonesia masih sangat terbatas. Hasil penelitian mengenai keragaman genetik dan heritabilitas sudah dilakukan pada bawang merah, di Indonesia oleh Herlina et al. (2019); dan Herlina et al. (2018); di Ethiophia oleh Degewione et al. (2011); dan bawang bombay (Allium cepa L.) di India oleh Solanki et al. (2015), dan Dangi et al. (2018). Oleh karena itu perlu dilakukan penelitian mengenai keragaman genetik dan heritabilitas bawang merah.

Tujuan penelitian untuk melihat keragaman genotipe dan fenotipe serta nilai duga heritabilitas arti luas karakter pertumbuhan, komponen hasil dan hasil bawang merah di dataran tinggi. Informasi yang diperoleh diharapkan dapat menjadi pedoman dalam perakitan varietas bawang merah di dataran tinggi, terutama dalam kegiatan seleksi pada karakter-karakter yang memiliki keragaman genetik dan heritabilitas yang tinggi.

\section{BAHAN DAN METODE}

Penelitian dilakukan dari bulan September sampai dengan Nopember 2019 di Lembang, $1.250 \mathrm{~m}$ dpl (Kab. Bandung Barat), Pacet $971 \mathrm{~m} \mathrm{dpl} \mathrm{(Kab.} \mathrm{Bandung),} \mathrm{dan}$ Samarang, $970 \mathrm{~m}$ dpl (Kab. Garut), karakter umum lokasi penelitian tersaji pada Tabel 1. Materi genetik yang digunakan dalam penelitian ini meliputi 12 genotipe bawang merah yang terdiri dari 7 (tujuh) klon koleksi Balai Penelitian Tanaman Sayuran (Balitsa) Lembang: dan B1, B19, B63, B72, B77, B102, dan B222, dan 5 (lima) varietas: Trisula, Bali karet, Maja cipanas, Bima brebes dan Sumenep.

Rancangan percobaan yang digunakan pada setiap lokasi yaitu menggunakan metode Rancangan Acak Kelompok (RAK) dengan 12 genotipe bawang merah sebagai perlakuan dan diulang 3 (tiga) kali. Plot disusun dengan ukuran $1 \times 6 \mathrm{~m}$ (lebar $\mathrm{x}$ panjang), terdiri dari 200 lubang tanam dengan jarak $20 \times 15 \mathrm{~cm}$. Pemupukan menggunakan pupuk kandang ayam (15 t $\left.\mathrm{ha}^{-1}\right)$, dolomit $\left(1,5 \mathrm{t} \mathrm{ha}^{-1}\right)$, pupuk SP 36 (250 $\left.\mathrm{kg} \mathrm{ha}^{-1}\right)$, diberikan sebelum tanam sebagai pupuk dasar. Pupuk susulan diberikan pada 2, 4 dan 6 minggu setelah tanam (MST) berupa larutan pupuk NPK 16.16.16 pada konsentrasi $8 \mathrm{~g} \mathrm{ll}^{-1}$ sebanyak $100 \mathrm{ml}$ $\operatorname{tanaman}^{-1}$. Selain itu juga dilakukan pemupukan menggunakan $\mathrm{KCl}$ White 
dengan cara disemprotkan pada konsentrasi $2 \mathrm{~g} \mathrm{l}^{-1}$ pada umur 3, 5 dan 7 MST. Pengendalian hama dan penyakit dilakukan dengan penyemprotan pestisida sesuai dengan OPT yang menyerang. Pengairan dan penyiangan dilakukan sesuai dengan stadia pertumbuhan.

Tabel 1. Karakter umum lokasi penelitian

\begin{tabular}{|c|c|c|c|}
\hline No & Lokasi & Ketinggian tempat & Jenis tanah*) \\
\hline 1 & $\begin{array}{l}\text { Desa Sirnasari Kecamatan Samarang } \\
\text { Kabupaten Garut Jawa Barat }\end{array}$ & $971 \mathrm{mdpl}$ & $\begin{array}{l}\text { Tanah sawah dengan } \\
\text { tekstur tanah liat }\end{array}$ \\
\hline 2 & $\begin{array}{l}\text { Desa Sukarame Kecamatan Pacet } \\
\text { Kabupaten Bandung Jawa Barat }\end{array}$ & 970 mdpl & $\begin{array}{l}\text { Tanah sawah dengan } \\
\text { tekstur tanah liat }\end{array}$ \\
\hline 3 & $\begin{array}{l}\text { Desa Cikole Kecamatan Lembang } \\
\text { Kabupaten Bandung Barat Jawa } \\
\text { Barat }\end{array}$ & $1.250 \mathrm{mdpl}$ & $\begin{array}{l}\text { Tanah kering, Andisol, } \\
\text { dengan tekstur tanah } \\
\text { lempung berdebu }\end{array}$ \\
\hline
\end{tabular}

Keterangan: $\left.{ }^{*}\right)$ Data tekstur tanah merupakan hasil analisis tanah di Laboratorium penguji terpadu Balitsa

Karakter yang diamati meliputi karakter pertumbuhan: tinggi tanaman $(\mathrm{cm})$, panjang daun $(\mathrm{cm})$, lebar daun $(\mathrm{mm})$, tebal daun $(\mathrm{mm})$, tinggi batang semu $(\mathrm{cm})$, diameter batang semu ( $\mathrm{mm})$, jumlah anakan, jumlah daun per rumpun, jumlah daun per umbi, dan persentase tanaman berbunga (\%); komponen hasil: diameter umbi (mm), tinggi umbi (mm), jumlah umbi per rumpun, berat umbi basah per rumpun $(\mathrm{g})$, berat umbi kering per rumpun (g), berat basah per umbi (g), berat kering per umbi $(\mathrm{g})$, susut bobot basah-kering umbi (\%), dan total padatan terlarut ( ${ }^{\circ}$ brix); dan hasil: hasil umbi basah per hektar $(\mathrm{t})$ dan hasil umbi kering per kering $(t)$.

Tabel 2. Analisis varian gabungan lokasi dan genotipe model acak

\begin{tabular}{llcl}
\hline \multicolumn{1}{c}{ Sumber variasi } & Derajat Bebas & Kuadrat tengah & Kuadrat Tengah Harapan \\
\hline Lokasi (I) & $\mathrm{l}-1$ & & - \\
Ulangan/Lokasi & $\mathrm{I}(\mathrm{r}-1)$ & & - \\
Genotipe (G) & $(\mathrm{g}-1)$ & $\mathrm{M}_{3}$ & $\sigma_{e}^{2}+r\left(\sigma_{g x l}^{2}\right)+r l\left(\sigma_{g}^{2}\right)$ \\
Genotipe x Lokasi & $(\mathrm{g}-1)(\mathrm{l}-1)$ & $\mathrm{M}_{2}$ & $\sigma_{e}^{2}+r\left(\sigma_{g x e}^{2}\right)$ \\
Error & $\mathrm{L}(\mathrm{r}-1)(\mathrm{g}-1)$ & $\mathrm{M}_{1}$ & $\sigma_{e}^{2} \ldots$ \\
\hline
\end{tabular}

Keterangan: $\mathrm{r}=$ banyaknya ulangan, I=lokasi, g=banyaknya genotipe, $\sigma_{g}^{2}=$ ragam genotipe, $\sigma_{g x e}^{2}=$ ragam interaksi, $\sigma_{e}^{2}=$ ragam lingkungan

Uji homogenitas dilakukan untuk mengetahui homogenitas dari varian galat pada masing-masing lokasi, sebelum dilakukan analisis varian gabungan. Uji homogenitas varian dari ketiga lingkungan dilakukan dengan menggunakan uji Bartlett (Gomez \& Gomez, 1995). Apabila $X^{2}{ }_{\text {hit }}>\mathrm{X}^{2}$ tabel maka galat tidak homogen dan analisa ragam dilakukan terpisah, tetapi bila $\mathrm{X}_{\text {hit }}^{2}<\mathrm{X}_{\text {tabel, }}^{2}$ maka varian galat homogen, sehingga dapat dilakukan analisa ragam gabungan. Uji Bartlett dihitung dengan menggunakan software PBSTAT GE (www.pbstat.com, 2020).

Karakter yang diamati dianalisis menggunakan analisis varian gabungan dengan menggunakan PKBT STAT 3.1 (www.pbstat.com, 2020). Analisis varian gabungan untuk beberapa lokasi mengikuti model acak untuk genotipe menurut 
Baihaki and Wicaksana (2005) (Tabel 2). Berdasarkan Tabel 1 dapat dihitung pendugaan parameter genetik yang meliputi pendugaan ragam genetik $\left(\sigma_{g}^{2}\right)$, ragam interaksi genetik $\mathrm{x}$ lingkungan $\left(\sigma_{g x e}^{2}\right)$, ragam lingkungan $\left(\sigma_{e}^{2}\right)$, ragam fenotipe $\left(\sigma_{f}^{2}\right)$, dan nilai koefisien keragaman genetik (KKG) serta nilai koefisien keragaman fenotip (KKF) diperoleh melalui:

$\sigma_{g}^{2}=\left(\mathrm{M}_{3}-\mathrm{M}_{2}\right) / \mathrm{rl}$

$\sigma_{g x e}^{2}=\left(\mathrm{M}_{2}-\mathrm{M}_{1}\right) / \mathrm{r}$

$\sigma_{e}^{2}=\mathrm{M}_{1}$

$\sigma_{f}^{2}=\sigma_{g}^{2}+\sigma_{g x e}^{2} / \mathrm{I}+\sigma_{e}^{2} / \mathrm{rl}$ dan

$K K G=\frac{\sqrt{\sigma_{g}^{2}}}{x} \times 100 \%$

$K K P=\frac{\sqrt{\sigma_{f}^{2}}}{x} \times 100 \%$

Menurut Sivasubramanian S. \& Menon (1973) dikutip Solanki et al. (2015) nilai KKG dan KKF: rendah (0-10\%), sedang (10-20\%) dan tinggi (>20\%).

Luas atau sempitnya nilai keragaman genetik suatu karakter ditentukan berdasarkan ragam genetik dan standar deviasi ragam genetik menurut rumus berikut :

$\sigma \sigma_{g}^{2}=\sqrt{\frac{2}{(r l)^{2}}\left(\frac{M_{3}^{2}}{d b_{g}+2}+\frac{M_{2}^{2}}{d b_{e+2}}\right)}$

$\sigma \sigma_{p}^{2}=\sqrt{\frac{2}{(r l)^{2}}\left(\frac{M_{3}^{2}}{d b_{g}+2}\right)}$

bila: $\sigma_{g}^{2}>2 \sigma \sigma_{g}^{2} \quad$ : keragaman genetiknya luas,

$\sigma_{g}^{2}<2 \sigma \sigma_{g}^{2} \quad$ : keragaman genetiknya sempit.

Nilai duga heritabilitas arti luas $\left(\mathrm{H}_{\mathrm{bs}}\right)$ adalah:

$\mathrm{H}_{\mathrm{bs}}=\left(\sigma_{g}^{2} / \sigma_{f}^{2}\right) \times 100 \%$

$$
=\left(\sigma_{g}^{2} /\left(\sigma_{g}^{2}+\sigma_{g x e}^{2} / \mathrm{I}+\sigma_{e}^{2} / \mathrm{rl}\right)\right) \times 100 \%
$$

dimana : $\sigma_{g}^{2}=$ ragam genotipe, $\sigma_{g x e}^{2}=$ ragam interaksi, $\sigma_{e}^{2}=$ ragam lingkungan, $\sigma_{f}^{2}=$ ragam fenotipe, $r=$ banyak ulangan, $I=$ banyak lokasi.

Nilai heritabilitas diklasifikasikan sebagai berikut : rendah $=\mathrm{H}_{\mathrm{bs}}<20 \%$, sedang $=20 \% \leq \mathrm{H}_{\mathrm{bs}}<50 \%$ dan tinggi $=\mathrm{H}_{\mathrm{bs}} \geq 50 \%$ (Mc Whirter (1979) dalam Halide and Paserang, 2020).

\section{HASIL DAN PEMBAHASAN}

1. Uji homogenitas

Hasil uji homogenitas varian galat $\left(x_{\text {hit }}^{2}\right)$ semua karakter yang diuji berkisar antara 0,00-0,28 (Tabel 3). Nilai $x_{\text {hit }}^{2}$ lebih kecil dari $x_{\text {tabel } 0,05}^{2}$ yaitu 5,99 , berarti varian galat semua karakter pada tiga lokasi adalah homogen. Varian galat yang berasal dari pengambilan sampel data pada masingmasing ulangan tidak berbeda nyata atau homogen berdasarkan uji homogenitas dengan menggunajan uji Barlett, sehingga dapat dilakukan uji gabungan.

\section{Interaksi genotipe $x$ lingkungan}

Karakter pertumbuhan, komponen hasil dan hasil dipengaruhi oleh faktor genetik, faktor lingkungan dan interaksi antara genotipe dan lingkungan. Faktor lingkungan dapat berupa lokasi, musim dan atau teknik budidaya. Hasil analisis varian gabungan (Tabel 3) menunjukkan lokasi, genotipe dan interaksi genotipe dan lokasi berpengaruh nyata dan berpengaruh sangat nyata pada karakter pertumbuhan, komponen hasil dan hasil 12 genotipe bawang merah di dataran tinggi. Lokasi berpengaruh sangat nyata pada karakter tinggi tanaman, panjang daun, jumlah daun per umbi, persentase tanaman berbunga, berat umbi basah per rumpun, berat umbi kering per 
rumpun, susut bobot basah-kering umbi, total padatan terlarut, hasil umbi basah per hektar dan hasil umbi kering per hektar. Hal ini sejalan dengan penelitian yang dilaporkan oleh Hermanto et al. (2017) dimana lokasi mempengaruhi umur panen, bobot panen, dan kekerasan buah tomat.

Genotipe berpengaruh sangat nyata terhadap semua karakter yang diamati, kecuali terhadap karakter jumlah daun per rumpun berpengaruh nyata. Hal ini menunjukkan adanya keragaman genetik yang berbeda nyata di antara genotipe. Demikian juga dengan yang telah dilaporkan Degewione et al. (2011) pada bawang merah genotipe berpengaruh nyata terhadap jumlah daun per rumpun dan berpengaruh sangat nyata terhadap tinggi tanaman, jumlah anakan per rumpun, panjang daun, lebar daun, tebal daun, jumlah umbi per rumpun, diameter umbi, tinggi umbi, berat kering per umbi, berat basah per rumpun dan total padatan terlarut. Hal ini dilaporkan juga pada bawang putih (Singh et al., 2018), pada paria (Rani et al., 2015) dan pada kacang hijau oleh (Hapsari, 2014).

Interaksi genotipe dan lokasi berpengaruh sangat nyata terhadap karakter panjang daun, lebar daun, tebal daun, tinggi batang semu, diameter batang semu, persentase tanaman berbunga, berat kering per umbi, total padatan terlarut, hasil umbi basah per hektar dan hasil umbi kering per hektar. Hasil ini menunjukkan bahwa karakter pertumbuhan, komponen hasil dan hasil bawang merah dipengaruhi oleh genotipe, lokasi dan interaksi genotipe dan lokasi, tetapi genotipe mempengaruhi seluruh karakter bawang merah. Hal ini sejalan dengan yang telah dilaporkan Hermanto et al. (2017) pada tomat interaksi genotipe dan lokasi mempengaruhi seluruh karakter hasil dan komponen hasil tomat. Sedangkan pada rami dimana lingkungan dalam hal ini berupa musim berpengaruh terhadap semua karakter kecuali jumlah biji per kapsul dan indek panen (Paul et al., 2015). Hal tersebut menunjukkan bahwa karakter pertumbuhan, komponen hasil dan hasil bawang merah dipengaruhi oleh genotipe, lokasi dan interaksi genotipe dan lokasi, tetapi genotipe mempengaruhi seluruh karakter bawang merah.

\section{Keragaman genetik}

Pengetahuan tentang tingkat keragaman genetik yang ada dalam populasi sangat penting untuk perbaikan genetik bawang merah lebih lanjut. Tabel 4 menyajikan keragaman genetik dan fenotip berdasarkan koefisien keragaman genetik (KKG) dan koefisien keragaman fenotip (KKF). KKG berkisar antara 4,70 \% untuk tinggi umbi dan 48,10\% untuk persentase tanaman berbunga, demikian juga untuk KKF berkisar antara 5,07 \% untuk tinggi umbi dan 49,01 \% untuk persentase tanaman berbunga. Umumnya setiap karakter memiliki kriteria keragaman KKG dan KKF yang relatif sama.

Keragaman rendah pada KKG dan KKF ( $<10 \%)$ terdapat pada karakter lebar daun ( $8,40 \%$ dan $9,74 \%)$, tebal daun $(8,55 \%$ dan $9,77 \%)$, tinggi batang semu $(7,29 \%$ dan $9,48 \%)$, dan tinggi umbi $(4,70 \%$ dan 5,07 $\%)$. Hal ini sejalan dengan penelitian Degewione et al. (2011) pada bawang merah yang melaporkan bahwa keragaman rendah pada KKG dan KKF terdapat pada karakter tinggi tanaman, total padatan terlarut dan waktu panen. Sedangkan pada bawang putih (Singh et al., 2018) KKG dan KKF rendah terdapat pada karakter tinggi umbi $(8,60 \%$ dan $8,76 \%)$. 
Tabel 3. Uji Barlett dan kuadrat tengah analisis varian gabungan karakter pertumbuhan, komponen hasil dan hasil 12 genotipe tanaman bawang merah di tiga lokasi dataran tinggi

\begin{tabular}{|c|c|c|c|c|c|c|}
\hline Karakter & $\begin{array}{c}\text { Uji } \\
\text { Barlett }\end{array}$ & $\begin{array}{l}\text { Lokasi } \\
(\mathrm{db}=2)\end{array}$ & $\begin{array}{l}\text { Ulangan/Lokasi } \\
\qquad(\mathrm{db}=6)\end{array}$ & $\begin{array}{l}\text { Genotipe } \\
(\mathrm{db}=11)\end{array}$ & $\begin{array}{l}\text { Genotipe*Lokasi } \\
\qquad(\mathrm{db}=22)\end{array}$ & $\begin{array}{c}\text { Galat } \\
(\mathrm{db}=66)\end{array}$ \\
\hline $\begin{array}{l}\text { Tinggi } \\
\text { tanaman }\end{array}$ & 0,00 & $828,35^{* *}$ & $46,59^{\text {tn }}$ & $161,99 * *$ & $36,47^{\text {tn }}$ & 26,21 \\
\hline Panjang daun & 0,00 & $366,3 * *$ & $12,55^{\text {tn }}$ & $113,04^{* *}$ & $15,67 * *$ & 6,13 \\
\hline Lebar daun & 0,00 & $7,27^{\mathrm{tn}}$ & $3,31 * *$ & $2,39 * *$ & $0,61 * *$ & 0,25 \\
\hline Tebal daun & 0,28 & $1,04^{\text {tn }}$ & $1,2^{* *}$ & $1,45^{* *}$ & $0,34 * *$ & 0,11 \\
\hline $\begin{array}{l}\text { Tinggi batang } \\
\text { semu }\end{array}$ & 0,18 & $67,17^{\text {tn }}$ & $14,15^{* *}$ & $3,70 * *$ & $1,55^{* *}$ & 0,69 \\
\hline $\begin{array}{l}\text { Diameter } \\
\text { batang semu }\end{array}$ & 0,18 & $1,89^{\text {tn }}$ & $3,44 * *$ & $5,25^{* *}$ & $1,36 * *$ & 0,86 \\
\hline $\begin{array}{l}\text { Jumlah } \\
\text { anakan }\end{array}$ & 0,04 & $4,38^{\text {tn }}$ & $1,81^{*}$ & $7,91^{* *}$ & $0,97^{\text {tn }}$ & 0,7 \\
\hline $\begin{array}{l}\text { Jumlah daun } \\
\text { per rumpun }\end{array}$ & 0,00 & $351,02^{\text {tn }}$ & $142,11^{*}$ & $123,71^{*}$ & $67,94^{\mathrm{tn}}$ & 53,1 \\
\hline $\begin{array}{l}\text { Jumlah daun } \\
\text { per umbi }\end{array}$ & 0,02 & $24,8 * *$ & $2,01^{\text {tn }}$ & $4,32 * *$ & $0,87^{\mathrm{tn}}$ & 1,29 \\
\hline $\begin{array}{l}\text { Persentase } \\
\text { tanaman } \\
\text { berbunga }\end{array}$ & 0,22 & $3420,99 * *$ & $115,6^{\text {tn }}$ & $9691,39 * *$ & $358,42 * *$ & 159,83 \\
\hline $\begin{array}{l}\text { Diameter } \\
\text { umbi }\end{array}$ & 0,23 & $4,54^{\text {tn }}$ & $9,14^{* *}$ & $72,23 * *$ & $3,26^{\text {tn }}$ & 2,3 \\
\hline Tinggi umbi & 0,23 & $23,98^{\text {tn }}$ & $11,9 *$ & $19,18^{* *}$ & $2,66^{\text {tn }}$ & 4,48 \\
\hline $\begin{array}{l}\text { Jumlah umbi } \\
\text { per rumpun }\end{array}$ & 0,00 & $35,66^{\text {tn }}$ & $9,93 * *$ & $25,09 * *$ & $2,89^{\mathrm{tn}}$ & 1,81 \\
\hline $\begin{array}{l}\text { Berat basah } \\
\text { umbi per } \\
\text { rumpun }\end{array}$ & 0,11 & $5680,27^{* *}$ & $462,3^{\text {tn }}$ & $2270,18^{* *}$ & $335,39^{\text {tn }}$ & 380,16 \\
\hline $\begin{array}{l}\text { Berat kering } \\
\text { umbi per } \\
\text { rumpun }\end{array}$ & 0,08 & $254,63 * *$ & $304,89^{\text {tn }}$ & $673,94 * *$ & $183,19^{\text {tn }}$ & 159,42 \\
\hline $\begin{array}{l}\text { Berat basah } \\
\text { per umbi }\end{array}$ & 0,02 & $56,57^{\text {tn }}$ & $12,9 *$ & $126,93 * *$ & $9,37^{\mathrm{tn}}$ & 5,75 \\
\hline $\begin{array}{l}\text { Berat kering } \\
\text { per umbi }\end{array}$ & 0,08 & $17,72^{t} n$ & $7,53 * *$ & $70,45^{* *}$ & $4,51 * *$ & 1,92 \\
\hline $\begin{array}{l}\text { Susut bobot } \\
\text { (basah-kering } \\
\text { umbi) }\end{array}$ & 0,27 & $1397,17^{* *}$ & $16,7^{*}$ & $108,62 * *$ & $24,23 * *$ & 7,3 \\
\hline $\begin{array}{l}\text { Total padatan } \\
\text { terlarut }\end{array}$ & 0,11 & $67,24 * *$ & $2,85^{\mathrm{tn}}$ & $52,58 * *$ & $3,89 * *$ & 1,45 \\
\hline $\begin{array}{l}\text { Hasil umbi } \\
\text { basah per } \\
\text { hektar }\end{array}$ & 0,00 & $403,13^{* *}$ & $23,36 * *$ & $80,64 * *$ & $19,59 * *$ & 7,2 \\
\hline $\begin{array}{l}\text { Hasil umbi } \\
\text { kering per } \\
\text { hektar }\end{array}$ & 0,05 & $145,39 * *$ & $7,35^{\text {tn }}$ & $30,9 * *$ & $9,64 * *$ & 3,51 \\
\hline
\end{tabular}


Pada padi KKG dan KKF yang rendah juga terdapat pada karakter hulling, miilling, dan kandungan amilosa (Nirmaladevi et al., 2015). Rendahnya nilai KKG dan KKF menunjukkan keragaman genetik yang sempit untuk sifatsifat tersebut sehingga sedikit kemungkinan seleksi dapat dilakukan karena pengaruh lingkungan. Peningkatan keragaman karakter ini dapat dilakukan dengan hibridisasi atau induksi mutagenesis untuk memperluas genetik yang diikuti oleh seleksi pedigree pada generasi lanjut (Nirmaladevi et al., 2015).

Karakter pertumbuhan komponen hasil dan hasil yang memiliki keragaman sedang (KKG dan KKF 10-20 \%) terdapat pada karakter panjang daun (10,93 \% dan 11,78 \%), jumlah anakan (14,14 \% dan 15,10\%), jumlah daun per umbi $(10,18 \%$ dan $11,40 \%)$, diameter umbi $(12,29 \%$ dan $12,57 \%)$, jumlah umbi per rumpun (18,16 \% dan 19,30 \%), berat basah umbi per rumpun $(15,71 \%$ dan $17,02 \%)$, berat kering umbi per rumpun $(11,86 \%$ dan 13,89 $\%)$, total padatan terlarut $(15,25 \%$ dan 15,85 $\%)$, hasil umbi basah per hektar (14,99 \% dan $17,22 \%)$ dan hasil umbi kering per hektar $(13,79 \%$ dan $16,62 \%)$. Hal ini sejalan dengan penelitian Degewione et al. (2011) pada bawang merah KKG dan KKF dengan keragaman sedang terdapat pada diameter umbi, lebar daun, hasil umbi per rumpun, jumlah anakan, tinggi umbi dan kepedasan. Dan pada bawang bombay penelitian Solanki et al. (2015) jumlah daun per tanaman dan ketebalan leher; penelitian Dangi et al. (2018) jumlah daun, panjang daun, lebar daun, tinggi batang semu, dan diameter batang semu, sedangkan pada bawang putih (Singh et al., 2018) ketebalan leher umbi, hasil umbi per tanaman, jumlah siung per umbi, berat per siung dan diameter siung pada bawang putih. Keragaman sedang menunjukkan adanya keragaman yang relatif moderat untuk karakter-karakter tersebut, yang dapat dimanfaatkan untuk perbaikan melalui seleksi pada generasi lanjut (Nirmaladevi et al., 2015).
Karakter pertumbuhan dan komponen hasil yang memiki keragaman tinggi (KKG dan KKF $>20 \%)$ terdapat pada karakter persentase tanaman berbunga (48,10\% dan 49,01\%), berat basah per umbi $(29,71 \%$ dan 30,87 \%), dan berat kering per umbi $(33,17 \%$ dan 34,29 $\%)$. Hasil penelitian ini sejalan dengan penelitian Degewione et al. (2011) pada bawang merah, KKG dan KKF tinggi terdapat pada karakter diameter daun, jumlah umbi per rumpun, berat basah per rumpun, berat kering umbi per rumpun, berat kering umbi, dan susut bobot umbi pada bawang merah dan lebar daun dan pada bawang putih (Singh et al., 2018) tinggi siung. KKG dan KKF yang tinggi menunjukkan keragaman yang tinggi mengindikasikan bahwa seleksi sederhana efektif berdasarkan karakter-karakter (Nirmaladevi et al., 2015) dan ekspresi fenotipik karakter-karakter tersebut akan menjadi indikasi yang baik dari potensi genetik (Degewione et al., 2011).

Nilai KKG dan KKF karakter tinggi tanaman (9,80\% dan $11,13 \%)$, diameter batang semu (8,56\% dan $10,80 \%$ ), jumlah daun per rumpun (6,99\% dan 10,41 \%), dan susut bobot basahkering umbi $(10,61 \%$ dan $12,51 \%)$ memiliki keragaman genetik rendah, tetapi keragaman fenotip sedang. Hasil perbedaan yang luas antara nilai KKG dan KKF menunjukkan pengaruh yang nyata faktor lingkungan terhadap sifat-sifat tersebut. Karena itu, akan tepat untuk mempertimbangkan penggunaan karakter tersebut disesuaikan dengan tujuan program perbaikan genetik bawang merah (Degewione et al., 2011).

Nilai KKF lebih tinggi daripada KKG pada semua karakter yang diamati. Hal yang sama dilaporkan pada bawang merah (Degewione et al. 2011), kacang hijau (Hapsari, 2014); padi (Nirmaladevi et al., 2015), bawang bombay Dangi et al. (2018), pada sawi (Muhammad \& Waluyo, 2019). Nilai KKF lebih tinggi daripada nilai KKG menunjukkan faktor lingkungan mempengaruhi karakter ini (Dangi et al., 2018). 
Tabel 4. Nilai ragam genetik $\left(\sigma_{g}^{2}\right)$; ragam interaksi $\left(\sigma_{g x e}^{2}\right)$, ragam lingkungan $\left(\sigma_{e}^{2}\right)$, ragam fenotip $\left(\sigma_{f}^{2}\right)$, koefisien keragaman genetik (KKG), koefisien keragaman fenotip (KKF), standar deviasi ragam genetik $\left(\sigma \sigma_{g}^{2}\right)$, standar deviasi ragam fenotip $\left(\sigma \sigma_{f}^{2}\right)$, heritabilitas $\left(\mathrm{h}^{2}\right)$ gabungan karakter pertumbuhan, komponen hasil dan hasil 12 genotipe bawang merah di tiga lokasi

\begin{tabular}{|c|c|c|c|c|c|c|c|c|c|}
\hline Karakter & $\sigma_{g}^{2}$ & $\sigma_{g x e}^{2}$ & $\sigma_{e}^{2}$ & $\sigma_{f}^{2}$ & KKG & KKF & $\sigma \sigma_{g}^{2}$ & $\sigma \sigma_{f}^{2}$ & $h^{2}$ \\
\hline Tinggi tanaman & 13,95 & 3,42 & 26,21 & 18,00 & $9,80(R)$ & $11,13(\mathrm{~S})$ & 7,09 (SM) & 7,06 (L) & $77,49(\mathrm{~T})$ \\
\hline Panjang daun & 10,82 & 3,18 & 6,13 & 12,56 & $10,93(\mathrm{~S})$ & $11,78(\mathrm{~S})$ & 4,94 (L) & 4,93 (L) & $86,14(T)$ \\
\hline Lebar daun & 0,20 & 0,12 & 0,25 & 0,27 & $8,40(R)$ & $9,74(R)$ & $0,10(\mathrm{SM})$ & $0,10(\mathrm{~L})$ & $74,48(T)$ \\
\hline Tebal daun & 0,12 & 0,08 & 0,11 & 0,16 & $8,55(R)$ & $9,77(R)$ & 0,06 (SM) & $0,06(\mathrm{~L})$ & $76,55(\mathrm{~T})$ \\
\hline $\begin{array}{l}\text { Tinggi batang } \\
\text { semu }\end{array}$ & 0,24 & 0,29 & 0,69 & 0,41 & $6,18(R)$ & $8,10(R)$ & $0,16(\mathrm{SM})$ & $0,16(\mathrm{~L})$ & $58,11(\mathrm{~T})$ \\
\hline $\begin{array}{l}\text { Diameter batang } \\
\text { semu }\end{array}$ & 0,43 & 0,28 & 0,52 & 0,58 & $9,62(\mathrm{R})$ & 11,18 (S) & 0,23 (SM) & $0,21(\mathrm{~L})$ & $74,10(T)$ \\
\hline Jumlah anakan & 0,77 & 0,09 & 0,70 & 0,88 & $14,14(S)$ & $15,10(\mathrm{~S})$ & $0,35(\mathrm{~L})$ & $0,34(\mathrm{~L})$ & $87,74(T)$ \\
\hline $\begin{array}{l}\text { Jumlah daun per } \\
\text { rumpun }\end{array}$ & 6,20 & 4,95 & 53,10 & 13,75 & 6,99 (R) & 10,41 (S) & 5,54 (SM) & 5,39 (L) & $45,08(S)$ \\
\hline $\begin{array}{l}\text { Jumlah daun per } \\
\text { umbi }\end{array}$ & 0,38 & $-0,14$ & 1,29 & 0,48 & $10,18(S)$ & $11,40(\mathrm{~S})$ & $0,19(\mathrm{~L})$ & $0,19(\mathrm{~L})$ & $79,86(T)$ \\
\hline $\begin{array}{l}\text { Persentase } \\
\text { tanaman } \\
\text { berbunga }\end{array}$ & $1,037,00$ & 66,20 & 159,83 & $1,076,82$ & $48,10(T)$ & 49,01 (T) & $422,42(\mathrm{~L})$ & $422,36(L)$ & $96,30(\mathrm{~T})$ \\
\hline Diameter umbi & 7,66 & 0,32 & 2,30 & 8,03 & $12,29(\mathrm{~S})$ & $12,57(\mathrm{~S})$ & 3,15 (L) & 3,15 (L) & $95,49(\mathrm{~T})$ \\
\hline Tinggi umbi & 1,84 & $-0,61$ & 4,48 & 2,13 & $4,70(R)$ & $5,07(R)$ & $0,84(\mathrm{~L})$ & $0,84(\mathrm{~L})$ & $86,13(\mathrm{~T})$ \\
\hline $\begin{array}{l}\text { Jumlah umbi per } \\
\text { rumpun }\end{array}$ & 2,47 & 0,36 & 1,81 & 2,79 & 18,16 (S) & $19,30(\mathrm{~S})$ & 1,09 (L) & 1,09 (L) & $88,48(T)$ \\
\hline $\begin{array}{l}\text { Berat basah umbi } \\
\text { per rumpun }\end{array}$ & 214,98 & $-14,92$ & 380,16 & 252,24 & $15,71(\mathrm{~S})$ & $17,02(S)$ & 99,14 (L) & 98,94 (L) & $85,23(T)$ \\
\hline $\begin{array}{l}\text { Berat kering umbi } \\
\text { per rumpun }\end{array}$ & 54,53 & 7,92 & 159,42 & 74,88 & $11,86(\mathrm{~S})$ & $13,89(\mathrm{~S})$ & $29,58(S M)$ & 29,37 (L) & $72,82(\mathrm{~T})$ \\
\hline $\begin{array}{l}\text { Berat basah per } \\
\text { umbi }\end{array}$ & 13,06 & 1,21 & 5,75 & 14,10 & $29,71(T)$ & $30,87(T)$ & $5,53(\mathrm{~L})$ & $5,53(\mathrm{~L})$ & $92,62(T)$ \\
\hline $\begin{array}{l}\text { Berat kering per } \\
\text { umbi }\end{array}$ & 7,33 & 0,86 & 1,92 & 7,83 & $33,17(\mathrm{~T})$ & $34,29(T)$ & 3,07 (L) & 3,07 (L) & $93,60(T)$ \\
\hline $\begin{array}{l}\text { Susut bobot } \\
\text { (basah-kering } \\
\text { umbi) }\end{array}$ & 9,38 & 5,64 & 7,30 & 12,07 & $9,68(R)$ & $10,98(S)$ & 4,76(SM) & 4,73 (L) & $77,69(\mathrm{~T})$ \\
\hline $\begin{array}{l}\text { Total padatan } \\
\text { terlarut }\end{array}$ & 5,41 & 0,81 & 1,45 & 5,84 & $15,25(\mathrm{~S})$ & $15,85(S)$ & $2,29(\mathrm{~L})$ & 2,29 (L) & $92,60(T)$ \\
\hline $\begin{array}{l}\text { Hasil umbi basah } \\
\text { per hektar }\end{array}$ & 6,78 & 4,13 & 7,20 & 8,96 & 14,99 (S) & $17,22(\mathrm{~S})$ & 3,53 (SM) & $3,51(\mathrm{~L})$ & $75,71(T)$ \\
\hline $\begin{array}{l}\text { Hasil umbi kering } \\
\text { per hektar }\end{array}$ & 2,36 & 2,04 & 3,51 & 3,43 & 13,79 (S) & $16,62(S)$ & 1,36 (SM) & $1,35(\mathrm{~L})$ & $68,76(T)$ \\
\hline
\end{tabular}

Keterangan: $\mathrm{R}=$ rendah; $\mathrm{S}=$ sedang; T=tinggi; $\mathrm{SM}=$ sempit; L=luas

Tetapi jika perbedaan nilai KKG dan KKF yang sempit $(<1)$ pada masing-masing karakter menunjukkan keragaman suatu karakter lebih disebabkan faktor genetik yang mengindikasikan resistensi relatif mereka terhadap keragaman lingkungan lingkungan (Dangi et al., 2018 ; Solanki et al., 2015)). Hal ini dapat disebabkan karena materi yang diuji berbeda latar belakang genetik (Hapsari, 2014) dan seleksi dapat dilakukan secara efektif melalui keragaman fenotipik.

Nilai ragam genetik dan ragam fenotipik didasarkan pada standar deviasi genetik dan fenotipik masing-masing karakter. Karakter tinggi tanaman, lebar daun, tebal daun, tinggi batang semu, diameter batang semu, jumlah daun per rumpun, berat kering umbi per rumpun, susut bobot basah-kering umbi, hasil umbi basah per 
hektar dan hasil umbi kering per hektar memiliki ragam genetik yang sempit, tetapi memiliki ragam fenotipik yang luas. Karakter yang memiliki keragaman genetik luas akan memiliki keragaman fenotipik luas, tetapi karakter yang memiliki keragaman genetik sempit belum tentu keragaman fenotipenya sempit (Priyanto et al., 2018). Hal ini menunjukkan fenotipe merupakan interaksi antara genotipe dengan lingkungan (Syukur et al., 2010).

Karakter panjang daun, jumlah anakan, jumlah daun per umbi, persentase tanaman berbunga, diameter umbi, tinggi umbi, jumlah umbi per rumpun, berat basah umbi per rumpun, berat basah per umbi, berat kering per umbi dan total padatan terlarut memiliki keragaman genotipe dan fenotipe yang luas. Hasil penelitian Hapsari (2014) pada padi ragam genetik dan fenotipe yang luas pada karakter tinggi tanaman, umur berbunga, umur masak, jumlah polong per tangkai, jumlah polong per tanaman, panjang polong, jumlah biji per polong, bobot 1.000 biji dan hasil biji per plot. Ragam genetik yang luas apabila galur berkerabat jauh, mendekati homosigot, dan berasal dari persilangan induk-induk yang berbeda latar belakang genetik (Trustinah and Iswanto, 2012). Ragam genetik dan fenotipe yang luas merupakan salah satu faktor keberhasilan program seleksi (Allard, 1960).

\section{Nilai duga heritabilitas}

Nilai duga heritabilitas arti luas $\left(\mathrm{H}_{\mathrm{bs}}\right)$ karakter-karakter pada 12 genotipe bawang merah berkisar antara 45,08 - 96,30\%. Semua karakter yang diamati memiliki nilai heritabilitas tinggi kecuali untuk karakter jumlah daun per rumpun dengan nilai heritabilitas sedang. Nilai heritabilitas tinggi yaitu pada karakter tinggi tanaman, panjang daun, lebar daun, tebal daun, tinggi batang semu, diameter batang semu, jumlah anakan, jumlah daun per rumpun, jumlah daun per umbi, persentase tanaman berbunga, diameter umbi, tinggi umbi, jumlah umbi per rumpun, berat basah umbi per rumpun, berat kering umbi per rumpun, berat basah per umbi, berat kering per umbi, susut bobot (basah-kering umbi) total padatan terlarut, hasil umbi basah per hektar dan hasil umbi kering per hektar menunjukkan pengaruh faktor genetik lebih besar dibandingkan faktor lingkungan dan memiliki peluang yang besar untuk terwariskan pada turunannya (Hermanto et al., 2017). Dengan demikian seleksi pada karakter-karakter tersebut dapat dilakukan pada generasi awal dibandingkan dengan karakter jumlah daun per rumpun yang memiliki heritabilitas sedang.

Singh et al. (2018) melaporkan pada 16 genotipe bawang putih semua karakter memiliki heritabilitas tinggi, berkisar antara $90,41 \%$ untuk total padatan terlarut dan 99,86 \% untuk lebar daun; Effendy et al. (2018) pada 34 aksesi ciplukan semua karakter memiliki heritabilitas tinggi, berkisar antara $58 \%$ untuk jumlah bunga per cabang tersier dan $99 \%$ untuk bobot per buah tanpa dan dengan kelopak; dan (Handayani \& Hidayat, 2016) pada 12 genotipe kedelai semua karakter memiliki heritabilitas tinggi kecuali karakter persentase biji keras memiliki heritabilitas sedang $(28,9 \%)$.

Karakter tanaman yang mempunyai nilai KKG tinggi belum tentu mempunyai nilai heritabilitas tinggi, dan sebaliknya. Pada penelitian ini didapatkan bahwa ada karakter yang mempunyai nilai KKG tinggi dan heritabilitas tinggi, KKG rendah/sedang dan heritabilitas tinggi, sehingga nilai KKG dan heritabilitas tidak selalu sebanding 
sama besar, disebabkan ada faktor lingkungan yang mempengaruhi nilai heritabilitas. Suatu karakter tanaman yang memiliki keragaman genetik yang rendah serta nilai heritabilitas yang tinggi menunjukkan bahwa secara populasi karakter tersebut seragam dan penampilan karakter tersebut sangat dipengaruhi oleh faktor genetik. Nilai KKG tinggi serta nilai heritabilitas yang rendah menunjukkan bahwa karakter tersebut mempunyai variasi yang besar, tetapi variasi karakter pada genotipe lebih besar dipengaruhi oleh lingkungan. Jika nilai KKG dan heritabilitas yang tinggi pada suatu karakter menujukkan bahwa karakter tersebut mempunyai pengaruh faktor genetik yang besar sehingga penampakan fenotipnya karakter akan lebih terekspresi sebagai pengaruh genetik dan sedikit dipengaruhi oleh lingkungan (Effendy et al., 2018)

\section{SIMPULAN}

1. Keragaman genotipe dan fenotipe bawang merah di tiga lokasi menunjukkan keragaman tinggi pada karakter persentase tanaman berbunga, berat basah per umbi, dan berat kering per umbi.

2. Semua karakter yang diamati memiliki nilai duga heritabilitas arti luas tinggi kecuali untuk karakter jumlah daun per rumpun nilai duga heritabilitasnya sedang.

3. Dengan nilai duga heritabilitas arti luas tinggi pada semua karakter kecuali untuk karakter jumlah daun per rumpun, maka seleksi bawang merah di dataran tinggi dapat dilakukan pada generasi awal, terutama seleksi yang dilakukan pada karakter dengan KKG dan KKF tinggi yaitu karakter persentase tanaman berbunga, berat basah per umbi, dan berat kering per umbi.

\section{UCAPAN TERIMA KASIH}

Terima kasih kepada Badan Litbang Pertanian yang telah membiayai kegiatan ini melalui DIPA Balitsa TA.2019 dan seluruh pihak yang telah membantu kegiatan ini.

\section{DAFTAR PUSTAKA}

Allard, R.W. (1960). Principles of Plant Breeding. J. Wiley \& Sons, New York. $485 \mathrm{p}$.

Baihaki, A., \& N. Wicaksana (2005) Interaksi Genotipe $x$ Lingkungan, Adaptabilitas, dan Stabilitas Hasil, dalam Pengembangan Tanaman Varietas Unggul di Indonesia. Zuriat 16(1): 1-8.

Dangi, R., A. Kumar, \& A. Khar (2018) Genetic Variability, Heritability, and Diversity Analysis in Short Day Tropical Onion. Indian J. Agric. Sci. 88(6): 140149.

Degewione, A., S. Alamerew, \& G. Tabor. (2011). Genetic Variability and Association of Bulb Yield and Related Traits in Shallot (Allium cepa Var. Aggregatum DON.) In Ethiopia. Int. J. Agric. Res. 6(7): 517-536.

Effendy, E., R. Respatijarti, \& B. Waluyo. (2018). Keragaman Genetik Dan Heritabilitas Karakter Komponen Hasil dan Hasil Ciplukan (Physalis sp.). J. Agro 5(1): 30-38.

Gomez, K., \& A. Gomez. (1995). Prosedur Statistik untuk Penelitian Pertanian. Universitas Indonesia, Jakarta. 698 
hal.

Halide, E.S., \& A.P. Paserang. (2020). Keragaman Genetik, Heritabilitas dan Korelasi Antar Kentang (Solanum tuberosum L.) yang Dibudidayakan di Napu. Biocelebes 14(1): 94-104. doi: 10.22487/bioceb.v14i1.15090.

Handayani, T., \& I.M. Hidayat. (2016). Keragaman Genetik dan Heritabilitas Beberapa Karakter Utama pada Kedelai Sayur dan Implikasinya untuk Seleksi Perbaikan Produksi. J. Hortik. 22(4):327.doi:10.21082/jhort.v22n4.2 012.p327-333.

Hapsari, R.T. (2014). Pendugaan Keragaman Genetik dan Korelasi Antara Komponen Hasil Kacang Hijau Berumur Genjah. Bul. Plasma Nutfah 20(2): 51-58.

Herlina, L., Reflinur, Sobir, A. Maharijaya, \& S. Wiyono. (2019). Genetic Diversity of Indonesian Shallots Based on BulbTunic Patterns and Morphological Characters. Indones. J. Agric. Sci. 20(1): 19-28.

Herlina, L., Reflinur, K. Nugroho, R.T. Terryana, \& Sobir. (2018). Genetic Diversity Analysis Using Resistance Gene Analog-Based Markers to Support Morphological Characterization of Shallots. Agrobiogen 14(2): 65-74.

Hermanto, R., M. Syukur, \& Widodo. (2017). Pendugaan Ragam Genetik dan Heritabilitas Karakter Hasil dan Komponen Hasil Tomat (Lycopersicum esculentum Mill.) di Dua Lokasi. J. Hortik. Indones. 8(1): 31.

Muhammad, R.F., \& B. Waluyo. (2019). AGROSAINSTEK Galur Sawi (Brassica juncea L.) Genetic Variability and Heritability of Agronomic Character Indian. Agrosainstek J. 3(2): 73-83.
Kementrian Pertanian. (2020). Rencana Strategis Kementrian Pertanian 20202024: Keputusan Menteri Pertanian Republik Indonesia Nomor: 259/Kpts/RC.020/M/05/2020.

Mutia, A.K., Y.A. Purwanto, \& L. Pujantoro. (2014). Perubahan Kualitas Bawang Merah selama Penyimpanan pada Tingkat Kadar Air dan Suhu yang Berbeda. J. Pascapanen 11(2): 108115.

Nasution, M.A. (2010). Analisis Korelasi dan Sidik Lintas Antara Karakter Morfologi dan Komponen Buah Tanaman Nenas (Ananas comosus L. Merr.). Crop Agro 3(1): 1-8.

Nirmaladevi, G., G. Padmavathi, S. Kota, \& V.R. Babu. (2015). Genetic Variability, Heritability and Correlation Coefficients of Grain Quality Characters in Rice (Oryza sativa L.). Sabrao J. Breed. Genet. 47(4): 424433.

Paul, S., S. Bhateria, \& A. Kumari. (2015). Genetic Variability and Interrelationships of Seed Yield and Yield Components in Linseed (Linum usitatissimum L.). Sabrao J. Breed. Genet. 47(4): 375-383.

Priyanto, S.B., M. Azrai, \& M. Syakir. (2018). Analisis Ragam Genetik, Heritabilitas, dan Sidik Lintas Karakter Agronomik Jagung Hibrida Silang Tunggal. Inform. Pertan. 27(1): 1-8.

Putrasamedja, S. (2010). Pengujian beberapa klon bawang merah dataran tinggi. J. Pembang. Pedesaan 10(2): 86-92.

Rani, K.R., C.S. Raju, \& K.R. Reddy. (2015). Variability, Correlation and Path Analysis Studies in Bitter Gourd (Momordica charantia L.). Agric. Sci. Dig. - A Res. J. 35(2): 106-110. 
Sari, V., Miftahudin, \& Sobir. (2017). Keragaman Genetik Bawang Merah (Allium cepa L.) Berdasarkan Marka Morfologi dan ISSR. J. Agron. Indones. 45(2): 175.

Singh, G., C.N. Ram, A. Singh, S. Prakash Shrivastav, \& P. Kumar Maurya. (2018). Genetic Variability, Heritability and Genetic Advance for Yield and its Contributing Traits in Garlic (Allium sativum L.). Int. J. Curr. Microbiol. Appl. Sci. 7(2): 1362-1372. doi: 10.20546/ijcmas.2018.702.165.

Solanki, P., P.K. Jain, S. Prajapati, N. Raghuwanshi, \& R.N. Khandait. (2015). Genetic Analysis and Character Association in Different Genotypes of Onion (Allium cepa L.). Int. J. Agric.
Environ. Biotechnol. 8(4): 783-793.

Syukur, M., S. Sujiprihati, R. Yunianti, \& K. Nida. (2010). Pendugaan Komponen Ragam, Heritabilitas dan Korelasi untuk Menentukan Kriteria Seleksi Cabai (Capsicum annuum L.) Populasi F5. J. Hort. Indones. 1(2): 74-80.

Trustinah, \& R. Iswanto. (2012). Keragaman bahan genetik galur kacang hijau. Pros. Semin. Has. Penelit. Tanam. Aneka Kacang dan Umbi: 465-472.

Visalakshi, M., C. Porpavai, \& M. Pandiyan. (2018). Correlation and Path Coefficient Analysis of Yield and Yield Associated Traits in Small Onion. Int. J. Curr. Microbiol. Appl. Sci. 7(7): 30653072. 